\title{
Effect of Girdling and Potassium Fertilization on Yield Efficiency and Fruit Quality of Apricot cv. Amal
}

Kabeel, H. ; M. M. Morsey and Y. I. El-Naggar

Hort. Res. Instit., ARC, Giza, Egypt

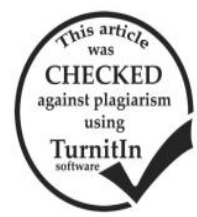

\section{ABSTRACT}

The present investigation has been carried out at El-Kanater Horticultural Research Station during both 2015 and 2016 seasons to study the effect of four levels of potassium soil applied either alone or combined with girdling treatment on some fruiting parameters and both fruit physical and chemical properties as well as leaf nutrient status of Amal apricot trees budded on Okinawa rootstock.Obtained data showed that, the investigated fruiting parameters (fruit set \% and yield either $\mathrm{kgs} / \mathrm{tree}$ or ton/feddan) were significantly increased with increasing the levels of $\mathrm{K}$ and girdled trees when compared to the control treatment. Moreover, fruit properties including both fruit physical characteristics i.e., fruit weight, volume, firmness, height, diameter and fruit shape index as well as fruit chemical properties (TSS \%, acidity $\%$ and TSS/acid ratio) were significantly improved as a result of the highest soil application level of $\mathrm{K}$ and girdled trees as compared with the control trees. In addition to that, leaf nutrient content of some macro-elements $(\mathrm{N}, \mathrm{P}$ and $\mathrm{K})$ were improved by the different investigated combination treatments under study from the standpoint of statistic during both 2015 and 2016 seasons. Generally, it could be conclude that, most of investigated combination treatments of $(\mathrm{K} \mathrm{x} \mathrm{G})$ resulted in a positive and a significant effect on all fruiting parameters, leaf nutrient contents and most fruit quality of Amal apricot fruit trees. Furthermore, the treatment of $\mathrm{K}$ at $1500 \mathrm{gm} /$ tree $\mathrm{x}$ girdling gave the best and the most effective combination treatment for increasing fruiting parameters and improving both the most physical and chemical properties and leaf nutrient contents of Amal apricot trees cultivated under condition of Qalyubeia Governorate.

Keywords: Potassium, Girdling, Apricot, Fruiting parameters, Fruit quality and Leaf nutritional status.

\section{INTRODUCTION}

It is well known that, apricot can be considered as one of the major and the most delectable, important popular and favourite deciduous fruit trees cultivated in Egypt along time ago. Since, it has an excellent flavor, nice taste and high nutritional value. Additionally, apricot is considered either as fresh ripe fruits or after industrial process. Increasing and improving both yield and fruit quality as well as reducing both the production costs and environmental pollution are the vital and important aims of investigators.

Potassium $(\mathrm{K})$ is considered one of the most important macro-elements applied as soil fertilizers. It plays a key nutritional and major role, second only to $\mathrm{N}$ in determining both fruit production and quality, Kilany and Kilany (1991), Awasthi et al. (1997) and Attala (1998) on apple; Gommings (1981), Mansour et al. (1986) and Kabeel (2004) on peach; Nageib et al. (1991) and apricot and Nasef (2000) on pear trees. Also, it influences many enzymatic reactions and is associated with almost every plant function. Moreover, it improves the efficiencies of plant water and sugar use for maintenance and normal growth function, however, it moves sugars from the site of photosynthesis to other storage sites. Besides, the rate photosynthesis drops sharply when plants are $\mathrm{K}$ deficient (Mongi and Tom, 2012).

On the other hand, girdling is common horticultural practices applied fruit crops for improvement of yield and fruit quality (El-Shikh et al. 1999; Ilha et al. 1999; ElBeacy, 2001 and Said et al. 2003). Fruit size and sugar content are an important quality for fresh apricot fruits. Hence, it was especialted that girdling may induce favourable effects on yield and fruit quality.

Therefore, the present investigation was carried out on apricot trees to study the effect of different levels of potassium $(\mathrm{K})$ soil applied either alone or combined with girdling or without girdling treatments on some fruiting parameters, fruit productivity and fruit characteristics as well as leaf nutrient status of apricot trees Amal cv.

\section{MATERIALS AND METHODS}

The present investigation has been under taken during the two successive seasons of 2015 and 2016 at the experimental farm of El-Kanater Horticultural Research Station, Qalyubia Governorate, Egypt. Uniform fruitful and healthy 8-year-old apricot trees, Amal cv. budded on Okinawa rootstock, grown in a clay loamy soil and planted at 5 meters under surface irrigation system. All trees received the same common agricultural practices.

Four levels of potassium soil applied in the form of potassium sulphate (48 \% K2O) i.e., 0.0, 500, 1000 and $1500 \mathrm{gm} /$ tree were added one dose after full bloom either alone or in-combined with the girdling treatment, which done on third week of March in both seasons of study by removing about $0.5 \mathrm{~cm}$-wide-ring of branches (about $20 \mathrm{~cm}$ above the bases of secondary branches). In addition to that, control trees did not receive any abovementioned treatments.

Accordingly, the investigated $\mathrm{K}$ levels, girdling and their combination treatments were as follows:

1 - Potassium at $0.0 \mathrm{gm} /$ tree (control treatment).

2- Potassium at $0.0 \mathrm{gm} /$ tree and girdling (G.) treatment.

3- Potassium (K) soil applied at $500 \mathrm{gm} /$ tree.

4- Potassium soil applied at $500 \mathrm{gm} /$ tree and girdling treatment.

5- Potassium soil applied at $1000 \mathrm{gm} /$ tree.

6- Potassium soil applied at $1000 \mathrm{gm} /$ tree and girdling treatment.

7- Potassium soil applied at $1500 \mathrm{gm} /$ tree.

8- Potassium soil applied at $1500 \mathrm{gm} /$ tree and girdling treatment.

The complete randomized block design was used for arranging the abovementioned eight treatments with two replicates whereas, each replicate was represented by a single tree, four main branches well distributed around the periphery of tree (one branch on each direction) were tagged and the following measurements were determined.

\section{1- Fruiting parameters:}

Percentage of fruit set: The total number of flowers at full bloom and the initial number of fruits at the end of blooming stage on the labeled shoots (branches) in all treatments were counted and recorded then the percentage of fruit set was calculated as the following equation:

\section{Number of set fruitlets}

Fruit set $(\%)=$

Total number of flowers at full bloom $\mathbf{x} 100$

Productivity (yield as $\mathbf{k g} /$ tree and ton/feddan): Tree yield was recorded at the time of harvesting (on May $13^{\text {th }}$ and May $10^{\text {th }}$ during the two seasons, respectively. 
The average yield per tree in $\mathrm{kg}$ for each treatment and yield (ton/feddan) were determined.

2- Fruit quality: Samples of mature fruits at harvesting time was carried out before their full ripening on May $13^{\text {th }}$ and $10^{\text {th }}$ in the two seasons of study, respectively. Samples of 30 random fruits per each treatment were used for determination of both physical and chemical properties.

Fruit physical properties: including the average values of fruit weight $(\mathrm{gm})$, fruit volume $\left(\mathrm{ml}^{3}\right)$, fruit dimensions (both fruit height and diameter in $\mathrm{mm}$.) fruit shape index (fruit height/ diameter ratio) and fruit firmness $\left(\mathrm{Ib} /\right.$ inch $\left.^{2}\right)$ was determined using pressure tester with 7/18 plunger (Magness and Taylor, 1982).

Fruit chemical properties: these properties were also estimated including the average percentage of fruit juice TSS by hand refractometer according to AOAC (2000), fruit juice titratable acidity (\%) according to the method described by Vogel (1968) was calculated and TSS/ acidity ratio was estimated by dividing TSS (\%) over total acidity (\%).

3- Nutritional status (leaf mineral content): leaf nutrient composition of some macro-elements i.e., (N, P and $\mathrm{K}$ ) were determined. The following procedures were used: Total $\mathrm{N}$ was determined by micro-Kjeldahl method as described by Pregl (1945). While, P determination was carried out colourmetrically according to Murphy and Riely (1962). Moreover, K was determined using the atomic absorption spectrophotometer (3300) according to the method described by Chapman and Pratt (1961).

All obtained data were statistically analyzed using the analysis of variance method according to Snedecor and
Cochran (1990). However, means were distinguished by the Duncan`s multiple range test (Duncan, 1955).

\section{RESULTS AND DISCUSSION}

\section{Fruiting parameters:}

In this regard, the percentage of fruit set and yield either as $\mathrm{kg} /$ tree or ton/feddan were the fruiting parameters investigated in response to the specific and interaction effects of the two investigated factors under study.

\section{A- Specific effect:}

Regarding the specific effect of potassium (K) as soil application at different levels i.e., 0.0, 500, 1000 and $1500 \mathrm{gm} /$ tree on some fruiting parameters (fruit set $\%$ and fruit yield either $\mathrm{kg} /$ tree or ton per feddan) of Amal cv., apricot, data in Table 1 displayed obviously that, all investigated fruiting parameters under study were responded statistically to tested $\mathrm{K}$ various levels. However, all investigated fruiting parameters increased significantly by increasing the level of potassium. Whereas, supplying of apricot trees cv., Amal with the highest level of potassium 1500 gm per tree resulted in statistically the highest values of fruit set $\%$ and the greatest yield expressed as either $\mathrm{kg} /$ tree or ton/feddan. On the other hand, an opposite trend was observed with apricot trees which received the lowest amount of potassium 0.0 gm per tree showed and produced significantly the least value of fruit set $\%$ and fruit yield per tree in $\mathrm{kg} \&$ ton/feddan. Moreover, both treatments at 1000 gm and $1500 \mathrm{gm} /$ tree were statistically in between when the abovementioned fruiting parameters were compared to that of the two other potassium soil added levels.

Table 1. Response of some fruiting parameters (fruit set \% and yield as either $\mathrm{kg} / \mathrm{tree} \mathrm{or} \mathrm{ton/feddan)} \mathrm{of} \mathrm{Amal}$ apricot cv., to the different levels of potassium soil applied, girdling and their combinations during both 2015 and 2016 seasons.

\begin{tabular}{|c|c|c|c|c|c|c|c|c|c|}
\hline \multirow{2}{*}{ Treatments } & \multicolumn{3}{|c|}{ Fruit set \% } & \multicolumn{3}{|c|}{ Yield (kg/tree) } & \multicolumn{3}{|c|}{ Yield (ton/fed) } \\
\hline & No. Gir. & Girdling & Mean* & No. Gir. & Girdling & Mean* & No. Gir. & Girdling & Mean* \\
\hline & & & & & season (2 & & & & \\
\hline$(\mathrm{K} \cap 0 \sim \mathrm{m})$ & $12.03 \mathrm{~g}$ & $14.76 \mathrm{ef}$ & $13.40 \mathrm{D}$ & $76.16 \mathrm{f}$ & $79.27 \mathrm{ef}$ & $77.72 \mathrm{D}$ & $12.95 \mathrm{~g}$ & $13.48 \mathrm{f}$ & $13.21 \mathrm{D}$ \\
\hline & $.64 \mathrm{fg}$ & $18 .($ & $4 \mathrm{C}$ & $78.92 \mathrm{ef}$ & $91.75 \mathrm{~d}$ & $85.34 \mathrm{C}$ & $12 \mathrm{f}$ & & $14.51 \mathrm{C}$ \\
\hline m) & & & & $81.21 \mathrm{e}$ & & & & & $16.59 \mathrm{~B}$ \\
\hline & $20.01 \mathrm{c}$ & 26. & $23.39 \mathrm{~A}$ & $102.40 \mathrm{c}$ & $121.8 \mathrm{a}$ & $112.1 \mathrm{~A}$ & & & $19.06 \mathrm{~A}$ \\
\hline & $6 \mathrm{~B}$ & & & 84.67B & $101.71 \mathrm{~A}$ & & & & \\
\hline & & & & $2^{\mathrm{II}}$ & season (2 & & & & \\
\hline & & & & $56.23 \mathrm{~g}$ & & & & & $11.08 \mathrm{D}$ \\
\hline & & & & $62.46 \mathrm{f}$ & 90. & & & & $13.00 \mathrm{C}$ \\
\hline & & & & & & & & & \\
\hline & & $27.02 \mathrm{a}$ & $24.08 \mathrm{~A}$ & & & $103.60 \mathrm{~A}$ & & & $17.66 \mathrm{~A}$ \\
\hline Mean** & $15.11 \mathrm{~B}$ & $20.90 \mathrm{~A}$ & & $72.50 \mathrm{~B}$ & $37 \mathrm{~A}$ & & $12.32 \mathrm{~B}$ & $16.31 \mathrm{~A}$ & \\
\hline
\end{tabular}

$*$ and ** refer to specific effect of $\mathrm{K}$ soil applied levels and girdling treatment, respectively. Values of each investigated characteristics obtained in every season were significantly distinguishing by capital and small letters for specific and interaction effects.

With respect to the response of abovementioned three investigated fruiting parameters to the specific effect of girdling, obtained results in the same Table indicated clearly that, all fruiting parameters (fruit set \%, yield as $\mathrm{kg} /$ tree and yield as ton per feddan) were significantly responded to girdled treatment during the two seasons of study. However, treated trees with girdling exhibited statistically the highest values of all investigated fruiting parameters over that of untreated trees which induced the lowest values from the standpoint of statistic. Such trends were detected during both the first and second of study.

B- Interaction effect:

Concerning the interaction effect of different treatments of $(\mathrm{K} \times \mathrm{G})$ combinations on abovementioned three fruiting parameters, data tabulated in Table 1 revealed that the highest values of each fruiting parameters in this study was always in significant relationship to treated trees both the highest level of $\mathrm{K}$ and girdling i.e., (1500 gm/tree $\mathrm{x}$ girdling) treatment. However, an opposite trend was noticed with untreated apricot trees ( $0.0 \mathrm{gm} \mathrm{K} \times$ No girdling) treatment. On the other hand, the other remain combination treatments were intermediate the abovementioned two extents with tendency of variability in their effectiveness regarding their interaction effect on all investigated fruiting parameters in this study. Such trend was true during both 2015 and 2016 seasons of experimental study.

Obtained results regarding the response of both fruit set $\%$ and yield to the $\mathrm{K}$ level are in harmony with those reported by Nageib et al. (1991) on apricot; Attala (1998) on apple; Nasef (2000) on pear and Kabeel (2004) on peach trees. Considering the influence of girdling, data are in conformity with those stated by Ilha et al. (1999) on 
Japanese plum; Powell and Howell (1985) on peach and Ibrahim and Bahlool (1979) on Furete avocado trees.

\section{2- Fruit quality:}

Fruit physical properties:

Fruit weight $(\mathrm{gm})$, volume $\left(\mathrm{ml}^{3}\right)$, fruit dimensions (height and diameter in $\mathrm{mm}$ ), firmness (ib/inch ${ }^{2}$ ) and fruit shape index (height/diameter ratio) of Amal apricot fruits were the evaluated physical characteristics pertaining their response to the specific and interaction effects of different variables of the two investigated factors (potassium levels and girdling treatments).

\section{A- Specific effect:}

Considering the average fruit weight (gm), volume $\left(\mathrm{ml}^{3}\right)$ firmness $\left(\mathrm{lb} / \mathrm{inch}^{2}\right)$, height and diameter in $\mathrm{mm}$ of Amal apricot cv. applied by the different potassium soil added levels, data in Table 2 indicated clearly that, they specifically responded during both 2015 and 2016 seasons of study. Whereas, the heaviest, biggest, the greatest values of firmness, height and diameter of apricot fruits were resulted by the highest level of potassium (1500 gm/tree) treated trees. Contrary to that, the lightest, smallest the least values of firmness, height and diameter of apricot fruits were obtained from those trees subjected to the control treatment, which received with the lowest level of potassium ( $0.0 \mathrm{gm} / \mathrm{no}$ added potassium). On the other hand, the other two potassium treatments recorded in between values with a tendency of variability in their effectiveness as compared to the abovementioned two extents. Such trends were true during the first and second seasons of study. Meanwhile, with respect to fruit shape index as affected by the soil applied of potassium level treatments, data in the Table 3 displayed obviously that the trend was so far to be the same approximately during both seasons of study. Since, the four levels of soil added treatments were equally effective from the standpoint of statistic except with those apricot trees subjected to highest levels of potassium $(1500 \mathrm{gm} / \mathrm{tree})$ treatment, which exhibited statistically the least value in fruit shape index during the first (2015) season only.

Regarding the specific effect of girdling treatment, data in the same Tables indicated clearly that, a positive relationship between fruit weight, volume, height and diameter from one hand and girdling treatment of apricot trees from another. However, girdled trees were increased significantly the fruit weight, volume, height during the two seasons but in the second season only with the fruit diameter as compared to the un-girdled trees. On the other hand, with regard to both fruit firmness and fruit shape index of Amal apricot cv. trees as influenced by the girdling treatment, data in Tables $2 \& 3$ revealed that, the trend was so firm to be the same during both seasons of study. However, differences between either girdled trees or un-girdled ones was completely absent from the standpoint of statistic during the first and second seasons of study.

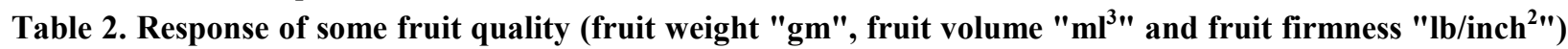
of Amal apricot cv. to the different levels of potassium soil applied, girdling and their combinations during both 2015 and 2016 seasons.

\begin{tabular}{|c|c|c|c|c|c|c|c|c|c|}
\hline \multirow{2}{*}{ Treatments } & \multicolumn{3}{|c|}{ Fruit weight (gm) } & \multicolumn{3}{|c|}{ F. volume $\left(\mathrm{ml}^{3}\right)$} & \multicolumn{3}{|c|}{ Fruit firmness $\left(\mathrm{lb} /\right.$ inch $\left.^{2}\right)$} \\
\hline & No. Gir. & Girdling & Mean* & No. Gir. & Girdling & Mean* & No. Gir. & Girdling & Mean* \\
\hline & & & & & & & & & 27 \\
\hline & $24.00 \mathrm{~cd}$ & & & $24.33 \mathrm{~cd}$ & $25.33 \mathrm{~cd}$ & $24.83 \mathrm{BC}$ & & & $50 \mathrm{~B}$ \\
\hline gm) & $25.35 \mathrm{~b}$ & & & $25.33 b c$ & $28.33 \mathrm{a}$ & $26.83 \mathrm{~A}$ & & & $75 \mathrm{~B}$ \\
\hline $00 \mathrm{gm})$ & $25.51 \mathrm{~b}$ & $27.63 a$ & $26.57 \mathrm{~A}$ & $26.27 \mathrm{~b}$ & 28. & $27.30 \mathrm{~A}$ & & & $6.74 \mathrm{~A}$ \\
\hline & $24.53 \mathrm{~B}$ & & & $24.95 \mathrm{~B}$ & $26.64 \mathrm{~A}$ & & & & \\
\hline & & & & & 0 & 16 & & & \\
\hline & & & $22.55 \mathrm{D}$ & $23.53 \mathrm{~d}$ & & $23.73 \mathrm{C}$ & $3.43 \mathrm{bc}$ & & $3.00 \mathrm{C}$ \\
\hline & $23.26 \mathrm{~d}$ & $24.02 \mathrm{~cd}$ & 23.6 & $24.53 \mathrm{~cd}$ & & $24.90 \mathrm{~B}$ & & & $3.89 \mathrm{~B}$ \\
\hline & $24.69 \mathrm{bc}$ & & 25.8 & & & & & & \\
\hline Potas & & & $26.59 \mathrm{~A}$ & & & $28.03 \mathrm{~A}$ & & $6.57 \mathrm{a}$ & $6.80 \mathrm{~A}$ \\
\hline Mean** & $23.67 \mathrm{~B}$ & $25.65 \mathrm{~A}$ & & $25.50 \mathrm{~B}$ & $26.70 \mathrm{~A}$ & & $4.67 \mathrm{~A}$ & $4.23 \mathrm{~B}$ & \\
\hline
\end{tabular}

* and ** refer to specific effect of $\mathrm{K}$ soil applied levels and girdling treatment, respectively. Values of each investigated characteristics obtained in every season were significantly distinguishing by capital and small letters for specific and interaction effects.

\section{B- Interaction effect:}

As for the interaction effect, data obtained in Tables 2

\& 3 revealed clearly that, the specific effect of each investigated factor under study was directly reflected on their interaction effect (combination). Hence, Amal apricot trees supplied with the highest potassium level $(1500 \mathrm{gm} /$ tree of potassium $\mathrm{x}$ girdling) treatment exhibited statistically the greatest values of fruit weight, volume, firmness, height and diameter of apricot fruits. However, the superiority of the aforesaid combination treatment over the other investigated treatments was clearly observed during both 2015 and 2016 seasons of study. Moreover, the least significant value of five fruit physical properties abovementioned were always in-concomitant to those apricot fruits included from the control treatment which was statistically the inferior. In addition to that, the remain other combination treatments came intermediate with a tendency of variability in their effectiveness as compared to the aforesaid two extents. On the other hand, data in Table 3 declared that the response of fruit shape index of Amal apricot trees treated with all combination treatments was statistically the same in most cases during the two seasons of study. In other words, the response was completely absent from the standpoint of statistic except with the treatment of potassium at highest level (1500 gm/tree) combined with either girdling or no girdling treatment. Such trends were true during both the first and second seasons of study.

\section{3-Fruit chemical properties:}

Referring the specific and interaction effects of the investigated two factors in this study on some fruit chemical characters (fruit juice TSS $\%$, total acidity $\%$ and TSS/acid ratio) of apricot fruits cv. Amal were evaluated during both 2015 and 2016 seasons of study.

\section{A- Specific effect:}

With respect to the response of both fruit juice TSS $\%$ and TSS/acid ratio to the specific effect of the investigated potassium treatments, data in Table 4 showed clearly that, both fruit characters were statistically responded to 
potassium soil applied at various levels as compared to the control. Since, the highest level of K (1500 gm/tree) exhibited the highest significant values and the richest fruits in their TSS \% and TSS/acid ratio. Meanwhile, the least values and the poorest fruits in their contents of TSS \% and TSS/acid ratio were always in concomitant to those apricot trees subjected to the control. Moreover, both treatments of $\mathrm{K}$ at $1000 \mathrm{gm}$ and $500 \mathrm{gm} /$ tree induced an intermediate values between the abovementioned two extents from the standpoint of statistic. Such trend was true during both seasons of study. Concerning the specific of $\mathrm{K}$ levels on total acidity $\%$, data in the same Table displayed obviously that, the highest acidity \% was always in relationship with such fruits produced by trees applied with the lower K levels (0.0, 500 and $1000 \mathrm{gm} /$ tree) however, these treatments resulted significantly in the greatest values of fruit juice total acidity $\%$ and differences between all the treatments did not reach level of significance during both seasons of study. Meanwhile, Amal apricot trees supplied with the highest level of $\mathrm{K}(1500 \mathrm{gm} / \mathrm{tree})$ treatment exhibited the least significant value and the poorest fruits in their content of total acidity. Such trend was detected during the two seasons of study.

Considering the fruit juice TSS \%, total acidity $\%$ and TSS/acid ratio as affected by the specific of girdling, treatments, data represented in the same Table displayed clearly that, the trend was so firm to be the same during both the first and second seasons of study. On the other hand, the response was completely absent from the standpoint of statistic during the two seasons except with TSS/acid ratio in the second season only their influence in fruit juice contents of three abovementioned studied fruit chemical characters of Amal cv. apricot trees was concerned.

Table 3. Response of some fruit quality (fruit height, diameter "mm" and fruit shape index) of Amal apricot cv. to the different levels of potassium soil applied, girdling and their combinations during both 2015 and 2016 seasons.

\begin{tabular}{|c|c|c|c|c|c|c|c|c|c|}
\hline \multirow{2}{*}{ Treatments } & \multicolumn{3}{|c|}{ Fruit height (cm) } & \multicolumn{3}{|c|}{ Fruit diameter (cm) } & \multicolumn{3}{|c|}{ Fruit shape index } \\
\hline & No. Gir. & Girdling & Mean* & No. Gir. & Girdling & Mean* & No. Gir. & Girdling & Mean* \\
\hline & & & & $1^{\mathrm{st}}$ & & & & & \\
\hline & & & & $33.00 \mathrm{~d}$ & 33. & & 0.980 & & \\
\hline $0 \mathrm{gm})$ & $33.33 \mathrm{~b}$ & $33.3^{\prime}$ & $33.50 \mathrm{AB}$ & $34.00 \mathrm{bc}$ & & & 0.980 & 0.9 & $76 \mathrm{~A}$ \\
\hline & 33.6 & 34. & $34.00 \mathrm{~A}$ & $33 \mathrm{a}$ & & 36.3 & 0.9 & & $0.936 \mathrm{~B}$ \\
\hline & & & & $33.42 \mathrm{~A}$ & $33.85 \mathrm{~A}$ & & & & \\
\hline & & & & & season $(20$ & 16) & & & \\
\hline & & & & & & & & & \\
\hline & & 33. & & $33.00 \mathrm{~b}$ & & & & & 00 \\
\hline & & & & $33.33 \mathrm{~b}$ & & & 1.010 & & 1.020 \\
\hline & 34.0 & & $35.00 \mathrm{~A}$ & & & $35.82 \mathrm{~A}$ & 0.953 & & 0.977 \\
\hline Mean** & $33.33 \mathrm{~A}$ & $33.42 \mathrm{~A}$ & & $33.17 \mathrm{~B}$ & $33.42 \mathrm{~A}$ & & 0.991 & 1.015 & \\
\hline
\end{tabular}

* and ** refer to specific effect of $\mathrm{K}$ soil applied levels and girdling treatment, respectively. Values of each investigated characteristics obtained in every season were significantly distinguishing by capital and small letters for specific and interaction effects.

\section{B- Interaction effect:}

Regarding the fruit chemical properties of Amal apricot fruits in response to the interaction effect of the different $(\mathrm{K} \times \mathrm{G})$ combination treatments, data obtained in Table 4 indicated that, the specific of each investigated factor was directly reflected in their combinations whereas, the highest level of K (1500 gm/tree) soil application combined with girdling treatment exhibited statistically the highest values and the richest fruits in their contents of TSS $\%$ and TSS \%/acid ratio. The superiority of the abovementioned combination treatment over the other

Table 4. Response of some fruit chemical properties (TSS \%, acidity \% and TSS/acid ratio or ton/feddan of Amal apricot $\mathrm{cv}$. to the different levels of potassium soil applied, girdling and their combinations during both 2015 and 2016 seasons.

\begin{tabular}{|c|c|c|c|c|c|c|c|c|c|}
\hline Treatments & \multicolumn{3}{|c|}{ TSS \% } & No. Gir. & $\begin{array}{l}\text { Acidity \% } \\
\text { Girdling }\end{array}$ & Mean* & $\begin{array}{l}\text { TS } \\
\text { No. Gir. }\end{array}$ & $\begin{array}{l}\text { S/acid rat } \\
\text { Girdling }\end{array}$ & $\begin{array}{l}\text { io } \\
\text { Mean* }\end{array}$ \\
\hline & & & & & season $(20$ & & & & \\
\hline Potassium (K 0.0gm) & $9.00 \mathrm{~b}$ & $9.17 \mathrm{~b}$ & $9.09 \mathrm{C}$ & $1.25 \mathrm{a}$ & 1.1 & $1.21 \mathrm{~A}$ & $7.40 \mathrm{~d}$ & $7.83 c$ & $7.61 \mathrm{D}$ \\
\hline & & & & & & & & & $7.88 \mathrm{C}$ \\
\hline & & & & & & & & & $8.50 \mathrm{~B}$ \\
\hline Po & $10.00 \mathrm{a}$ & $10.00 \mathrm{a}$ & $10.00 \mathrm{~A}$ & & & & & $10.00 \mathrm{a}$ & $10.00 \mathrm{~A}$ \\
\hline Mean** & & $9.58 \mathrm{~A}$ & & $1.17 \mathrm{~A}$ & $1.09 \mathrm{~A}$ & & & $8.67 \mathrm{~A}$ & \\
\hline & & & & & & & & & \\
\hline & & & & $1.37 \mathrm{a}$ & 1.3 & & & & $6.60 \mathrm{D}$ \\
\hline & $9.00 \mathrm{~cd}$ & & & & $1.20 \mathrm{a}-\mathrm{c}$ & 1.26 & & & $7.21 \mathrm{C}$ \\
\hline & & & & $1.13 b c$ & & & & $8.75 b$ & $8.60 \mathrm{~B}$ \\
\hline (K 1500) & $9.77 b$ & $10.33 \mathrm{a}$ & $10.05 \mathrm{~A}$ & $1.03 \mathrm{~cd}$ & $0.88 \mathrm{~d}$ & $0.95 \mathrm{C}$ & & $11.73 \mathrm{a}$ & $9.62 \mathrm{~A}$ \\
\hline Mean** & $9.28 \mathrm{AB}$ & $9.48 \mathrm{~A}$ & & $1.22 \mathrm{~A}$ & $1.12 \mathrm{~A}$ & & $7.30 \mathrm{~B}$ & $8.72 \mathrm{~A}$ & \\
\hline
\end{tabular}

$*$ and $* *$ refer to specific effect of $\mathrm{K}$ soil applied levels and girdling treatment, respectively. Values of each investigated characteristics obtained in every season were significantly distinguishing by capital and small letters for specific and interaction effects.

Also, data declared that the response of total acidity percentage to the interaction effect was completely absent investigated combinations was clearly observed during the two seasons of study. Contrary to that Amal apricot trees subjected to both the control treatments either with girdling or without girdling resulted in a significant the least values and the poorest fruits in their TSS \% and TSS/acid ratio contents. Such trends were detected during both 1 st and 2 nd seasons of study. In addition, the other combination treatments were in between the aforesaid two extents with a relative tendency of effectiveness. from the standpoint of statistic for all investigated combination treatments except with the treatment of (1500 
gm $\mathrm{K} /$ tree $\mathrm{x}$ girdled trees), which showed the lowest statistically value and the poorest fruits in their total acidity content during both 2015 and 2016 seasons of study.

The obtained results concerning the response of both fruit physical and chemical properties of apricot trees under study to K soil applied were supported by findings of several investigators such as Kilany and Kilany (1991), Awasthi et al. (1997) on apple; Nageib et al. (1991) on apricot, Nassef (2000) on pear, Commings (1981), Mansour et al. (1986) and Kabeel (2004) on peach trees.

Meanwhile, the influence of girdling treatment was concerned, the obtained data are in accordance with the findings of Fernandez et al. (1987), North et al. (1988), De-Villiers et al. (1990), El-Sherbini (1992); Agusti et al. (1998) and El-Beacy (2001) on peach, Ilha et al. (1999) on plum and Said et al. (2003) on apricot.

\section{Leaf nutrient status:}

\section{A- Specific effect:}

Data in Table 5 displayed obviously that regarding the leaf macro elements contents $(\mathrm{N}, \mathrm{P}$ an $\mathrm{K}$ ) of Amal apricot trees in response to the specific effect of potassium soil applied levels, it is quite evident that, all treatments resulted in a considerable and significant increase in leaf macro-nutrient contents ( $\mathrm{N}, \mathrm{P}$ and $\mathrm{K}$ ) as compared to the 0.0 gm potassium treatment during both seasons of study. However, the highest significant values of $\mathrm{N}, \mathrm{P}$ and $\mathrm{K}$ leaves content were exhibited by trees subjected to the higher level of potassium (1500 gm/tree), which was the most effective treatment followed by both treatments (1000 gm and $500 \mathrm{gm} \mathrm{K} /$ tree), respectively in the two seasons of study. On the other hand, an opposite trend was observed with those trees supplied with $0.0 \mathrm{gm}$ potassium/tree treatment, which was significantly the inferior in the all cases as exhibited the lowest values of $\mathrm{N}, \mathrm{P}$ and $\mathrm{K}$ contents during the first and second seasons of study.

Regarding the specific effect of the investigated girdling treatments, data obtained in the same Table indicated clearly that both girdling treatments, (girdling or without girdling) did not differ pertaining their specific effect on the leaf macro nutrient $(\mathrm{P}$ and $\mathrm{K}$ ) contents however, Amal apricot trees treated with girdling or without were statistically the same as leaf $\mathrm{P}$ and $\mathrm{K}$ contents in the two seasons of study. Moreover, untreated trees with girdling (trees without girdling) treatment was induced significantly the greatest value and the richest leaves in their $\mathrm{N}$ content as compared to both 2015 and 2016 seasons of experimental study.

\section{B- Interaction effect:}

Referring to the interaction effect of the different combinations treatments of $(\mathrm{K} \times \mathrm{G})$ on the leaf macro nutrient $(\mathrm{N}, \mathrm{P}$ and $\mathrm{K})$ contents of the Amal apricot trees, data in Table 5 revealed clearly that, apricot trees subjected to the higher level of $\mathrm{K}$ combined with untreated rees with girdling $(1500 \mathrm{gm} /$ tree $\mathrm{x}$ No girdling) combination treatment exhibited generally the highest values of $\mathrm{N}, \mathrm{P}$ and $\mathrm{K}$ contents during both the first and second seasons of study. The superiority of the abovementioned combination treatment over the other investigated ones was clearly observed through the two experimental seasons of study. Furthermore, the treatment of girdling only during both the first and second seasons resulted statistically in the lowest value of $\mathrm{N}, \mathrm{P}$ and $\mathrm{K}$ contents. In addition to that, other $(\mathrm{K} \mathrm{x}$ $\mathrm{G})$ combinations treatments were intermediate the abovementioned two extents with a tendency of variability in their effectiveness. Such trend was true during both 2015 and 2016 seasons of study.

Table 5. Response of some macro - nutrient elements (N, P and K) of Amal apricot leaves to the different levels of $K$ soil applied, girdling and their combinations during both 2015 and 2016 seasons.

\begin{tabular}{|c|c|c|c|c|c|c|c|c|c|}
\hline \multirow{2}{*}{ Treatments } & \multicolumn{3}{|c|}{ Nitrogen (\%) } & \multicolumn{3}{|c|}{ Phosphorus (\%) } & \multicolumn{3}{|c|}{ Potassium (\%) } \\
\hline & No. Gir. & Gir. & Mean & No. Gir. & Gir. & Mean & No. Gir. & Gir. & Mean \\
\hline & & & & $1^{\text {st }}$ & season $(20$ & 15) & & & \\
\hline $\operatorname{lm}(\mathrm{K} 0.0 \mathrm{gm})$ & $2.27 \mathrm{c}$ & $2.10 \mathrm{~d}$ & $2.1 \mathrm{C}$ & $0.290 \mathrm{~d}$ & $0.290 \mathrm{~d}$ & $0.290 \mathrm{~B}$ & $2.47 \mathrm{~d}$ & $2.51 \mathrm{~d}$ & $2.49 \mathrm{D}$ \\
\hline & $53 \mathrm{ab}$ & 2.3 & & $0.310 \mathrm{bc}$ & $0.295 \mathrm{~cd}$ & $0.301 \mathrm{AB}$ & bc & & \\
\hline$(\mathrm{K} 1000 \mathrm{gm})$ & $2.57 \mathrm{a}$ & $2.33 \mathrm{c}$ & 2.4 & $0.315 \mathrm{~b}$ & $0.310 \mathrm{bc}$ & $0.306 \mathrm{~A}$ & $3.25 \mathrm{~b}$ & & $3.24 \mathrm{~B}$ \\
\hline & 2.6 & $2.40 \mathrm{bc}$ & & $0.34 \mathrm{a}$ & 0.3 & $0.315 \mathrm{~A}$ & & & $3.56 \mathrm{~A}$ \\
\hline & 2 & $2.30 \mathrm{~B}$ & & $0.314 \mathrm{~A}$ & $0.304 \mathrm{AB}$ & & & & \\
\hline & & & & $2^{\text {Ind }}$ & season $(20$ & 16) & & & \\
\hline & & & & $10 \mathrm{c}$ & & & & & $2.70 \mathrm{D}$ \\
\hline & & & & Obc & & & & 3.2 & $3.25 \mathrm{C}$ \\
\hline Pota & $2.80 \mathrm{ab}$ & $2.67 \mathrm{~b}$ & $2.73 \mathrm{~B}$ & $0.340 \mathrm{~b}$ & $0.330 \mathrm{bc}$ & $0.335 \mathrm{~B}$ & $3.37 \mathrm{~b}$ & $3.30 \mathrm{~b}$ & $3.34 \mathrm{~B}$ \\
\hline & & & $2.90 \mathrm{~A}$ & & $0.347 \mathrm{~b}$ & $0.356 \mathrm{~A}$ & & $3.73 \mathrm{a}$ & $3.75 \mathrm{~A}$ \\
\hline & & & & $0.336 \mathrm{~A}$ & $0.324 \mathrm{AB}$ & & & $3.24 \mathrm{~A}$ & \\
\hline
\end{tabular}

* and ** refer to specific effect of $\mathrm{K}$ soil applied levels and girdling treatment, respectively. Values of each investigated characteristics obtained in every season were significantly distinguishing by capital and small letters for specific and interaction effects.

Data obtained on the effect of $\mathrm{K}$ level on leaf $\mathrm{N}, \mathrm{P}$ and $\mathrm{K}$ contents are in agreement with those reported by Awasthi et al. (1997), Attala (1998), Nasef (2000), Kabeel (2004) and El-Nagger (2009) on some deciduous fruit species. They revealed that leaf $\mathrm{N}, \mathrm{P}$, and $\mathrm{K}$ contents significantly increased by increasing the rate of $\mathrm{K}$ soil application. Meanwhile, other investigators, El-Beacy (2001) on peach and Said et al. (2003) on apricot, mentioned a similar trend to that noticed regarding the response of leaf $\mathrm{N}, \mathrm{P}$ and $\mathrm{K}$ contents to girdling treatments.

\section{REFERENCES}

Agusti, M. I. Andreu, M. Juan, V., Almela and L. Zacarias (1998). Effects of ringing branches on fruit size and maturity of peach and nactarine cultivars. J. Hort. Sci. Biotech., 73 (4): 537-540.
Allan, P. A. P. George, R.J. Nissen and T.S. Rasmussen (1993). Effects of girdling time on growth, yield and fruit maturity of the low chill peach cultivar Florida prince. Aust. J. Exp. Agric. 33 (6): 781-785.

AOAC (2000). "Official Methods of Analysis (17 $7^{\text {th }}$ ed.). Association of Official Analytical Chemists" Washington, D.C.

Attala, E. S. (1998). Effect of potassium fertilization on Anna apple trees grown in sandy soil of Egypt. Egypt Jour. Agric. Res., 75 (2): 709-717.

Awasthi, R. P.; N. S. Kath and G. Dev (1997). Influence of rate and method of potassium application on growth, yield, fruit quality and leaf mineral status of apple. Hort. Abst., 67 (11) 9178. 
Chapman, H.D. and F. Pratt (1961). "Methods of Analysis for Soils, Plants and Water'. Univ. of Calif., 35 (5): 6-7.

Commings, G. A. (1981). Potassium fertilization increases yield and quality of peaches. Better Crisp in Plant Food., 64 (Autumn) 20-21.

Cutting, J.G.M. and M.C. Lyne, (1993). Girdling and the reduction in shoot xylem sap concentration of cytokimins and gibberellins in peach. J. hort. Sci. 68 (4) : $619-626$.

De-Villiers, H.; J. G.M. Cutting, G. Jacobs and D. K. Strydom (1990). The effect of girdling on fruit growth and internal quality of "Culemborg" peach. J. Hort. Sci., 65 (2): 151-155.

De vaio, C., A. petito and M. Buccheri, (2001). Effect of girdling on gas exchange and leaf mineral content in the "independence" nectarine. J. Plant Nutr., 24 (7) : $1047-1060$.

Duncan, D. B. (1955). Multiple range and multiple F tests. Biometrics, 11: 1- 42.

El-Beacy, A.B. (2001). Effect of thinning and girdling on yield and fruit quality of peach. M. Sc. Thesis, Fac. of Agric., Mansoura Univ., 56 p.

El-Nagger, Y. I. (2009). Physiological studies on fertilization of young apricot trees "Canino" cultivar. Ph.D. Thesis, Fac. of Agric. Moshtohor, Benha University, Egypt.

El-Shaikh, A.A., B.M. Khalil and A. Y. Hamza (1999). The effect of girdling and some growth regulators on fruit drop of persimmon. Egypt. J. Agric. Res., 77 (4): $1707-1724$.

El-Sherbini, N.R., (1992). The effect of girdling on hastening fruit maturity and quality of some peach cultivars. Bull. Fac. Agric., Univ. Cairo, 43 (2): Supplement: 723-735.

Fernandez-Escobar, R.; R. Martin; P. Lopez-Rivares and M. Paz-Suarez (1987). Girdling as a means of increasing fruit size and earliness in peach and nectarine cultivars. J. Hort. Sci., 62 (4): 463-468.

Ibrahim, I. M. and S. Bahlool (1979). The effect of girdling on flowering, fruiting and vegetative growth of avocado trees. Agric. Res. Rev. Cairo, 57 (3): 55-66.

Ilha, L.L.H.; G.A.B. Marodin, E. Seibert and C.I.N. Barradas (1999). Effect of thinning and trunk girdling on growth, production and quality of Japanese plums. Pesquisa Agropecuaria Brasileira, 12: 2211-2217, (C.F. Hort. Abst. 70 (7): 5589).
Kabeel, H. (2004). Influence of different rates of nitrogen and potassium on vegetative growth, fruiting aspects, fruit characteristics and leaf mineral composition of Meet-Ghamr peach trees. Minufiya, J.Agric., Res., 29, (4): 215-234.

Kilany, A. E. and O. A. Kilany (1991). Effect of potassium and boron nutrients on growth, yield and fruit quality of Anna apple trees. Bull. Fac. of Agric., Cairo, Univ., 42 (2): 415-428.

Magness, J. R. and G. F. Taylor (1925). An improved type of pressure tester for the determination of fruit maturity. U.S. Dept. Agric. Circ., 350 8p.

Mansour, N. M.; El-Gebeely and A.D. Shaltout (1986). Effect of potassium sulphate on fruit characters of peach trees. Egypt. J. Hort., 13 (1): 35-42.

Mongi, Z. and O. Tom (2012). Potassium (K) for citrus trees. $\mathrm{http} / / \mathrm{edis}$.ifas.ulf.edu/topic series citrus trees nutrients.

Murphy, J. and J. P. Riely (1962). A modified single method for the determination of phosphorus in natural water. Anal. Chemi. Acta, 27:31-36.

Nageib, M. M.; M. M. Saleh and L. E. Hagagg (1991). Effect of potash fertilization on yield and fruit quality of Amar apricot trees. Annals, Agric. Sci. Ain Shams Univ. Cairo, 36 (2): 633-637.

Nassef, A. A. H. (2000). Physiological studies on the effect of mineral fertilization on growth and fruiting of LeConte pear trees. M. Sc. Thesis, Fac. of Agric. Moshtohor, Zagazig Univ.

North, M.; J. D. Stadler and H. De-Villiers (1988). Effect of cyanamide and girdling on yield, fruit size and quality of De wet peach. South Afr. J. Plant Soil., 5 (4): 224-226.

Powell, A. A. and J. C. Howell (1985). Peach growers. Increase size with girdling. In: Amer. Fruit Grower, 105 (1): 12-14.

Pregl, E. (1945). Quantitative Organic Microanalysis 4th ed. J. \& A Charchill, L.T.D. London.

Said, I.A., Fawzia M. Eissa and Eman, A. Kandil (2003). Effect of winter pruning, hand thinning and girdling on Canino apricot growth, yield, and quality. Minia J. Agric. Res. and Develop., 23 (2): 301-328.

Snedecor, G.W. and W.G. Cochran (1980). "Statistical Methods". 7th ed., Iowa State Univ. Press Amer. Iowa, USA pp.85-86.

Vogel, A. (1968). A Text Book of Quantitative Inorganic Analysis. Longmans, New York, pp. 1216.

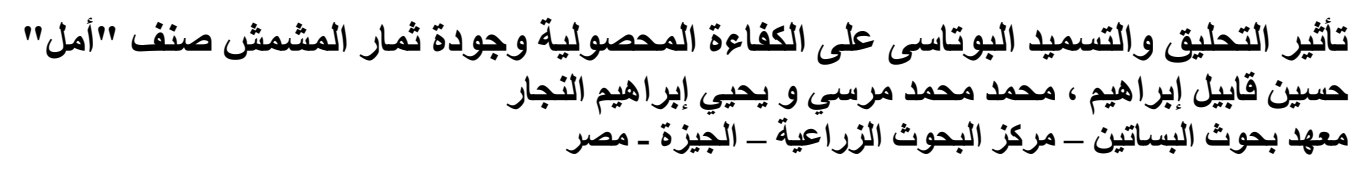

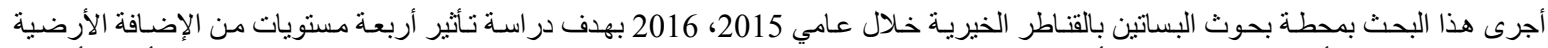

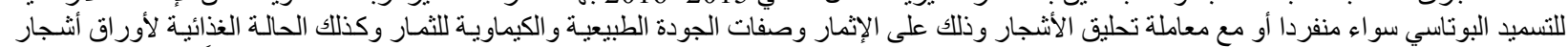

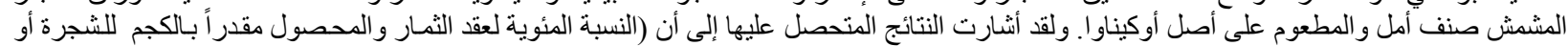

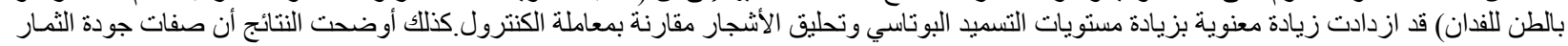

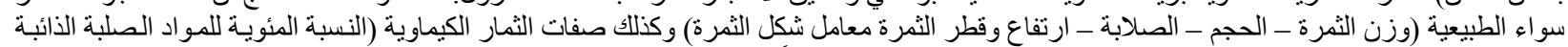

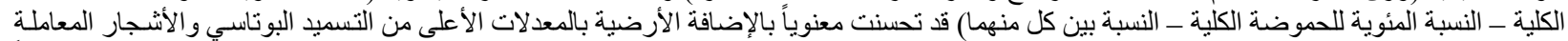

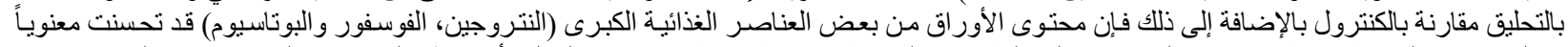

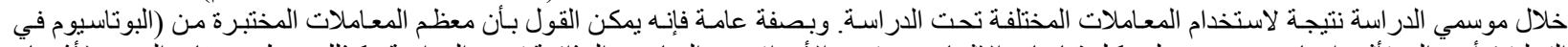

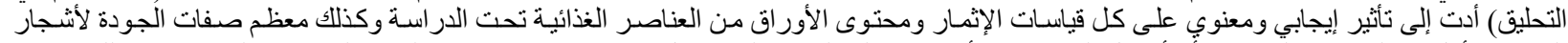

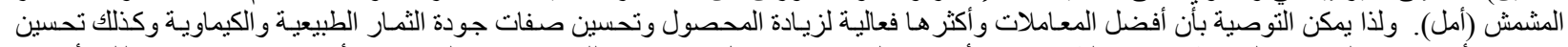

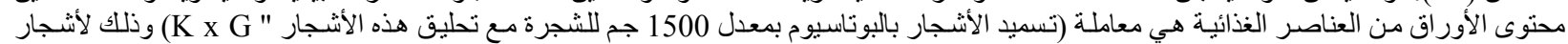
المشمش صنف (أمل) المنزر عة تحث ظروف العذبة منطقة محافظة القليوبية. 